Michał A. Michalski

Adam Mickiewicz University in Poznań

Faculty of Social Sciences

Institute of Cultural Studies

e-mail: mmichal@amu.edu.pl

\title{
Consumer social responsibility ${ }^{*}$
}

\begin{abstract}
In our contemporary literature and academic discourse, we often see how popular the topic of corporate social responsibility is. It will be argued that another problem, tightly linked to this issue, and strongly influencing the business environment is the consumer behaviour. This second part of business relations is often associated rather with legal demands and customer protection. The purpose of my article is to show how consumer social responsibility can help not only the corporations but also those involved in the market exchange to contribute to the common good and improve quality of millions of transactions people make every day. To become real, this responsibility needs effort - courage to witness by expressing consumer's opinion and education. The first aspect shows how important action is in revealing values and introducing ethics into everyday market activity, the second shows that emphasizing basic economic education and expecting thorough information from companies can help build and enhance consumer awareness. This article also attempts to demonstrate the contributions of Catholic Social Thought to the problem of social responsibility.
\end{abstract}

Keywords: consumer social responsibility, corporate social responsibility, ethics, witness, common good

JEL Classification: M14, P46

\footnotetext{
* The article is an updated version of the paper published in Polish in the Annales. Ethics in Economic Life, 11(1), 181-192.
} 
Ethics today requires the full participation by all involved in the problem.

Gerard I. Nierenberg (1987, p. 20)

\section{Balance of responsibility}

To begin, I want to explain why I chose this topic. After studying many texts in the field of business ethics, I noticed that the main emphasis is being put on the issue of enterprise behaviour. One regularly encounters the discussions about the corporate social responsibility. Many efforts are made by economic organizations trying to find the ways to incorporate social responsibility into everyday activities. However, not enough attention is paid to the issue of consumers' social responsibility. ${ }^{1}$ There are not too many sources dealing with this subject. There are publications regarding customer-management relations, and some that deal with the activities of consumer organizations. The latter, although they have played an important role in business for several decades and actually contributed to the development of the social responsibility of the consumers have mainly focused on the legal aspects. These are often used as intermediaries for clients who are struggling with companies in lawsuits. Therefore, they are treated rather as opponents and "supervisors" of enterprises. Despite the contribution of these organizations to economic life, not a real change can occur without an involvement of the consumers. The social responsibility of the consumer should therefore improve the cooperation between enterprises and their clients. It should be a necessary counterweight to business activities, which alone cannot create a situation of equilibrium. ${ }^{2}$

\section{New image of interdependence and responsibility}

To be sure, the old prescriptions of the "neighbor" ethics-justice, charity, honesty, and so on-still hold in their intimate immediacy for the nearest, day-by-day sphere of human interaction. But this sphere is overshadowed

\footnotetext{
${ }^{1}$ Lewicka-Strzałecka draws attention to the exceptional and exaggerated importance of consumption in the modern world: "One of the most important roles played by man in the modern world is the role of the consumer. Other roles-an employee, an employer, a representative of a specific profession, a parent, a superior, a subordinate etc. are sometimes performed only in certain periods of life, sometimes only by certain persons. While, we are all consumers, from birth to death, whether we like it or not. Consumption has now far gone beyond its constitutive functions, which it fulfills in nature, which consists of sustaining the functioning and development of organisms, so consumption in this broad sense is a characteristic that has little to which a modern man is entitled" (2006, p. 11).

${ }^{2}$ It is also important to recognize the differences between corporate responsibility and consumer responsibility. The first one is chosen, the second one is given. Taking into account another criterion both can be negative responsibility. However, in order to shape and transform economic life more and more, the commitment of both parties should take the form of positive responsibility more and more clearly, and it is its shape in the case of corporate social responsibility, which I want to write about here (cf. Lewicka-Strzałecka, 2006, pp. 9-10).
} 
by a growing realm of collective action where doer, deed, and effect are no longer the same as they were in the proximate sphere, and which by the enormity of its powers forces upon ethics a new dimension of responsibility never dreamed of before.

Hans Jonas (1985, p. 6)

The globalisation, a multidimensional process that seems to be affecting all aspects of humanity, is making its imprint in every country. People are afraid of it, and the same time, they hope that it will improve their lives. It is a source of opportunities and threats. Among its many manifestations, one can observe a growing awareness and tendency to express and use human rights. Because of cultural, political, social and economic transformations, people are increasingly making use of their freedom - whether it brings good or bad outcomes. It is linked to the political modernization that paradoxically deprives politics of power and borders (Beck, 2002, p. 292). Consequently, more often it is citizens who make their own choices, and not-like it was previously - that the state does it instead of them. At the same time, societies are experiencing shrinking social security because states and their governments are withdrawing from providing public services more and more. It is a stimulus and a signal for people, which inform them that their surroundings are changing radically and that they will probably have to make some decisions that they may have never made before. The social space "abandoned" by the state and its agencies is an area that encourages and even demands civic initiatives. ${ }^{3}$ It is an opportunity to improve civic virtues that will support the creation of a global civil society (Dylus, 2005, pp. 139-140), also called - according to the language of economics - a global society of services (p. 78).

This huge transformation is also noticeable in the field of business. Over the last thirty years, societies have experienced unparalleled changes. One of the effects of the growing awareness of the human rights is an increase in consumer awareness. It began decades ago and is continuing. In some regions and countries, the levels of awareness are high and in others, the people are catching up. Another tendency on the rise is a kind of "consumerist slavery"- the excessive consumption (consumption over needs) (Dylus, 2005, p. 22). ${ }^{4}$

The last manifestation of the changes described is work carried out by consumers (cf. Beck, 2002, p. 324). Although, their efforts often go unnoticed in the labour market, these are related to consumer freedom. Currently, people have the opportunity to purchase and use new products or services. Instead of going to the bank to withdraw money, people may use the ATMs and do it whenever it is convenient for them-making the banking hours irrelevant. The same applies to eating choices. One may eat at a traditional restaurant with

\footnotetext{
${ }^{3}$ Although there are great opportunities, I am far from an optimistic — even utopian — view that everyone is able to see them and use them equally skillfully (and that only his resourcefulness will depend on the result of his efforts). Rather, I am of the opinion that there will always be those who will not succeed, and those who will need additional support.

${ }^{4}$ There is more and more talk about compulsive buying disorder-addiction to shopping. Cf., for instance, Szwarc, 2006, p. 164.
} 
waiters, or one may opt for a self-service restaurant. The consumer decides on his or her work as a result of one's choice. ${ }^{5}$ One may prefer more freedom in choosing, touching, sniffing, when shopping in a large self-service store, and not mind "weightlifting" when placing goods in the shopping cart, putting them at the cash register, reloading them in the cart and putting them in the car.

\title{
3. Consumer' testimony in a civil market economy
}

\begin{abstract}
Nathaniel Hawthorne wrote: The greatest obstacle to being heroic is the doubt whether one may not be going to prove one's self a fool; the truest heroism is to resist the doubt, and the profoundest wisdom is to know when it ought to be resisted, and when to be obeyed.
\end{abstract}

Gerard I. Nierenberg (1987, p. 28)

One slogan, which appeared years ago during the election campaign in Poland, intended to encourage people to express political preferences and participate in elections, accurately describes the situation of consumers. ${ }^{6}$ It reads, "If you do not vote-you cannot complain." Often, the percentage of citizens taking part in the political elections is treated as a measure to show whether a given society deserves to be called civil or not. Similarly, a similar criterion for the number of consumers expressing their opinions may help determine whether a society is a civil market economy. Certainly, the comparison of post-communist and capitalist countries would show that the first of them have a large backlog in this area (which does not mean that in democratic and free market countries consumer awareness must be obviously and automatically high, although they probably have more experience and longer traditions, e.g. in the field of ethical investment ${ }^{7}$ ). In Poland, there is a slow but noticeable increase in consumer awareness, which had no chance of developing during the communist regime and a centrally controlled economy, when it was almost impossible to implement human rights and civil liberties. Increasingly, Poles see that expressing their own opinions is not only desirable but also necessary.

\footnotetext{
${ }^{5}$ It is possible to argue whether the consumer is fully aware of the real cost of their purchases. The alternative transaction cost is not always easy to see and measure.

6 "Consumer power has more scope than the power of voters who vote once in a while and not everyone does. However, everyone, willingly or not, votes through systematically repeated acts of buying and decides about the success or failure of companies. The purchase plebiscite takes place every day, and its result can very quickly influence the course of events and remove unwanted companies from power" (Lewicka-Strzałecka, 2006, pp. 118-119).

${ }^{7}$ The wording of socially responsible investment (SRI) is also used. The genesis of institutions operating on such principles dates back to the third decade of the twentieth century in Great Britain. Their flourishing took place at the end of the twentieth century. In recent years, there has been talk about the need to reform the crisis and distort the identity of many SRI funds, which in practice differs little from other investment institutions. Cf. Lewicka-Strzałecka, 2006, pp. 39-43, 50.
} 
Every enterprise needs information to operate. Business organizations collect data through multiple research projects, but this is mainly anonymous and onedimensional information that mainly provides numbers and simplified statements. ${ }^{8}$ Their quality and character are undoubtedly different from the opinion expressed by the "flesh and blood" consumer, who speaks directly: "I like this, I do not like that." I believe that this way of expression can be more convincing for the opinions of decision-makers in companies. Such signals may at the same time undermine the faith of those who trust that it is enough to follow the indications of the invisible hand of the market, and to profitably satisfy the needs of the target groupstatistical, "invisible)" (or poorly visible) buyers - will be only a matter of time.

When consumers make it clear as to what is important to them, they send a clear signal that they care about how society produces and increases wealth. They become examples for enterprises, but also for those who study and prepare to work in business - it is harder to teach students sensitivity and ethical sense towards the consumer without specific examples, showing that this side of trade relations is ready to actively participate in them and shape them (cf. Nierenberg, 1987, p. 18). Those buyers who react responsibly become witnesses of values probably shared by the majority of society, but not disclosed - and therefore, in some way absent. In our modern world, ruled by the morality of intention, the only available way to show that someone believes in the existence of good is to adopt a witness attitude (Delsol, 2003 , pp. $117,121-122)^{9}$ that is not able to satisfy being a merely passive, "statistical" consumer.

\section{The language of buying}

I buy, therefore I like, accept and support!

Michal A. Michalski

This section will deal with the problem of communicating the client's point of view to the company. Expressing opinions is not only limited to calling the helpline or writing a letter to the company. In modern marketing literature, much attention is paid to the issue of consumer complaints. Research shows that only a small percentage (10\%) of dissatisfied customers complain (cf. Shaw, 2001, pp. 224-225), the rest simply never return. ${ }^{10}$ More and more companies are beginning to understand that the complaining customer is

\footnotetext{
${ }^{8}$ It must be emphasized here that their results are not an exhaustive description of reality.

${ }^{9}$ This applies to the relationship between faith and the deeds described in the Epistle of St. James (James 2:14-17).

${ }^{10}$ Some of the dissatisfied customers would continue to use the offer of the company because they do not have access to alternative offers, for example for financial, geographical reasons, etc. However, it should be expected that as soon as this problem is resolved, they would not cooperate with an unsatisfactory supplier.
} 
a blessing, because it is a sign that he cares, and provides valuable information on the quality of services and products.

The decision not to buy is an important message from the client or the public. Unfortunately, there are companies that do not understand this. Such companies run the risk of "falling out" of the market. At the same time, the language of buying seems to be forgotten and its message underestimated by many consumers. Everyone who purchases a product or service invests their goods (not only financial), agrees to the terms of the agreement (regardless of whether it is in writing or not), declaring that the buyer accepts the arrangements and rules according to which the seller acts. The buyer is always able to choose and is not forced to buy a particular product. Another problem occurs when the consumer is cheated and simply does not realize it - then it is difficult to expect responsible behavior if he is not aware of the defect of the contract. ${ }^{11}$

A purchase decision is a way of manifesting values. ${ }^{12}$ These values are invisible and the buyer makes them visible if he really cares about them, e.g., a visible sign of approval for pornography and adultery is buying products from the porn industry. Whenever the buyers have the impression that their trust is abused through misleading advertising or fraudulent commercial practices, they should remember that they may act and that their vote matters. Complaints are often timeconsuming and energy-intensive requiring collecting information, and dealing with bureaucratic structures and procedures that may discourage any action. ${ }^{13}$ In many instances, one may have to wait a long time for the desired changes and improved legal regulations to appear. In comparison, an individual or collective boycott seems easier and more accessible.

Despite the above-mentioned difficulties, knowledge and proper use of the language of buying turns out to be fruitful when we observe a growing number of business entities who respond to signals sent by buyers, e.g. by declaring and engaging in ethical investing (cf. footnote 5).

\section{A climate for responsibility}

Responsibility is personal.

Chantal Delsol (2003, p. 215)

One may assume that responsibility is always someone's responsibility - to exist, it needs an individual subject. Without this, it is only a rhetorical issue.

\footnotetext{
${ }^{11}$ Freedom is, therefore, a necessary condition for an important contract. The story of Nelson Mandela's refusal to be released under certain conditions is a good example: Mandela demanded an unconditional release before he could negotiate with Botha's government: "Only a free person can negotiate. Prisoners cannot enter into contracts" (Nierenberg, 1987, p. 29).

${ }^{12}$ A comprehensive set of proposals for citizen-consumer activity was proposed by Al Fritsch (2006).

${ }^{13}$ A question may arise whether the case of the complaints procedure and their settlement are not designed so as to discourage potential applicants from the outset.
} 
It is important that a consumer possesses the basic competencies to understand the complexity of modern economic processes. A lack of economic knowledge can become a serious problem that may impair the consumers. It is difficult to engage in business relations without understanding why and what is happening within a transaction or its consequences. Great disproportions in education certainly contribute to the situation in which large portions of society become passive recipients of the market activity. Therefore, it seems reasonable to attend to the education in this area-e.g. to teach the basics of economics at a primary level. ${ }^{14}$

The second issue concerns over-specialization, which leads to different divisions. This is manifested by the emergence of specific ghettos resulting from narrow specialization that leads to a relative isolation of various social and professional groups. In various areas of our economic systems that "discover" more and more forms of work organization and exchange, and also "employ" advanced technology, "dialects" are created that perform descriptive and communication functions. Unfortunately, this development has negative sides-these highly specialized "languages" exclude from the circle of discussion those participants who are unable to communicate using them. The inability to understand specialist vocabulary becomes a serious shortage that makes it difficult to be a conscious consumer. The society is divided into two groups: the first onebetter educated, composed, among others, of university and economics faculties graduates, who are able to understand, for example, everyday economic news, and the second, unaware of the market reality, unable to reflect on the whole of the processes in which it participates and various connections that connect it with other-often distant in time and space-events. ${ }^{15}$

The last question is whether companies are able to do something about providing information and education to help consumers. Perhaps part of the money spent on - mostly biased and one-sided-advertising messages could be devoted to reliable and understandable information that would gradually cure our societies of the economic illiteracy they suffer. It seems possible to gradually transform the economic reality - a not very clear one, complicated and difficult to understand. Since it is not surprising that we require openness and transparency from public institutions, why would it be a strange requirement for companies to be the same, when they actually serve the public interest - which most of them declare (cf. MacIntyre, 1997, p. 244). More information means more potential knowledge. If consumers and businesses are able to use it properly, it helps all.

\footnotetext{
${ }^{14}$ Analogically to education in the field of civic knowledge, which does not concern only the sphere of political activity.

${ }^{15}$ Dividing a society in two groups is a significant simplification. Certainly, the reality is much more complex and probably getting the right education is not a guarantee that one fully understands the economic reality.
} 


\section{Catholic social teaching and social responsibility-The Church and the social character of man}

Do not be satisfied with mediocrity.

John Paul II (1981)

Free market society needs not only consumers but also responsible individuals, capable of hard work and creative action.

Rocco Buttiglione (2000, p. 27)

The concept of responsibility and emphasizing the social dimension of humanity are among the most important issues of the Church's teaching. This sentence is not cutting-edge although considering academic texts and discussions on corporate social responsibility, one would say that for many it could be a novelty. ${ }^{16}$

The call of the Church's social doctrine to be responsible does not indicate exactly who should bear more, and who should bear less responsibility, but rather invites all those involved in social life to take responsibility as much as possible, depending on the role and vocation. The echo of this invitation is heard many times: it takes the form of a call to "care for your brother" (Matthew 18:10-20; 1 John 4:7-21 and many others). This is inscribed in the Gospel and means to take care not only for your life, but also for the lives of others, both in the temporal and eternal dimensions. It also takes the form of a general call to commitment, deeply rooted in the Church's teaching - to read the signs of the times and respond to the challenges we face (cf. Gaudium et spes, Centesimus Annus, Sollicitudo rei socialis, and Laborem exercens among others). This is the same call that was heard by the first man in the Garden of Eden - to go and replenish the Earth and subdue it - to discover and manage it for the benefit of man and the glory of God. It is a vocation to care for the proper development of humanity - which will not be either underdevelopment or hyper-development (John Paul II, 1987, 28)—which are abnormal and destructive phenomena present in the modern world.

The Church's social teaching proposes solidarity and subsidiarity as essential tools for truly responsible human development. The first of these, defined by John Paul II $(1987,38)$ as "strong and lasting" will to engage on behalf of "the common good," it is the opposite of conformism, which presupposes homogeneity rather than unity and non-engagement, thus being subject to current conditions (cf. Al-

\footnotetext{
${ }^{16}$ In A. Lewicka-Strzałecka's book Odpowiedzialność moralna $w$ życiu gospodarczym, in the part devoted to the promoters of corporate social responsibility in Poland, no word was given to the Church and its social teaching. The situation is not an exception. There may be two reasons. Either the academic authors often do not see the Church's contribution in this area and are not aware of the content of the Church's documents, or the Church and its members are still making too little effort in this area (an example of the Church's interest in the current problems of corporate social responsibility may be, among others, the conference The Good Company. Catholic Social Thought and Corporate Social Responsibility in Dialogue, which took place in Rome in 2006).
} 
ford \& Naughton, 2006, pp. 78, 184; John Paul II, 1991, 15). Both of these nonviolent attitudes make not only the consumer but also the civic social responsibility troublesome. Subsidiarity means,

a community of a higher order should not interfere in the internal life of a community of a lower order, depriving the latter of its functions, but rather should support it in case of need and help to coordinate its activity with the activities of the rest of society, always with a view to the common good. (John Paul II, 1991, 48)

Using the language of social responsibility, one could say that the role of the consumer is to react to the level at which he is involved.

Catholic social teaching also raises the problem of consumerism, which is the result of the alliance of the market and libertinism. In this combination, market values are the only ones that are taken into account in society, so everything gradually becomes a commodity (cf. Buttiglione, 2000, p. 27). This is a suicidal tendency because society needs much more value to exist than a set of those that are inscribed in the market economy system. ${ }^{17}$ At the individual level, this means that being a consumer is only a part of being a man who, in search of fulfilment, must enter the area of management, but also exceed it. The defence of values other than the market is a warning against thinking in purely materialistic terms that make it difficult to imagine - and therefore, to take into account - the spiritual and moral side effects of economic activity. At the same time, the social teachings of the Church are an invitation to accept a true and full vision of the human being - created as a spiritual-psycho-physical unity-responsible for the good or bad use of his freedom.

\section{What about ethics?}

Ethical values have this special feature that they are meaningless in words, and they only mean when the subject becomes their hostage - not any individual, but a free subject because the act made under compulsion cannot have a moral value. Man becomes a subject only as a hostage and a witness of values which he himself pointed out.

Chantal Delsol (2003, p. 124) ${ }^{18}$

\footnotetext{
17 “As history demonstrates, a democracy without values easily turns into open or thinly disguised totalitarianism” (John Paul II, 1991, 46).

${ }^{18}$ The problem of practising virtues is also described by Gerard I. Nierenberg, although his position differs from Chantal Delsol's opinion. It seems that Nierenberg blames both the solutions and the underlying values. It is unclear as to his meanings. Should the ethics follow and adapt to changing conditions, or vice versa? He writes: "Philosophy, law and ethics, to be effective in a dynamic world must be made vital enough to keep pace with the progress of life and science. In recent civilization, ethics, because controlled by theology and law, which are static could not duly influence the dynamic, revolutionary progress of technique and the steadily changing conditions of life; and so we witness
} 
In recent years, one can observe and hear vivid discussions on ethical issues in science, education, politics, economics and religion. Much attention and power are devoted for companies to create codes of ethics and employ ethics managers. One may wonder if this is a sign showing that we live in a time during which humanity appreciates moral standards more, or perhaps our current situation is the result of a crisis of ethics that compels us to reflect and act.

Undoubtedly, the Western world is experiencing a serious fall of morality, which is admitted reluctantly. ${ }^{19}$ Its traditional Judeo-Christian ethics, which helped Europe build its identity, today arouse suspicion, especially among those who profess and practice "faith" in the Enlightenment paradigm. One of the serious ethical problems of modernity is the double morality experienced in social life when organizational morality meets individual morality. ${ }^{20}$ This problem of different moral standards has enormous consequences in all areas. In business, it generates common stereotypes, such as the one according to which the moral point of view is the opposite of financial prudence and efficiency (Goodpaster \& Matthews Jr., 1997, p. 97). The opinions such as the following are not rare:

I do not know any investment advisor I would allow to decide on my behalf in any other matter than just making profit [...] The greatest advantage of these specialists [...] is their limitations; they should not allow themselves too much vision of the world, because it would distract them. (Goodman, 1971, p. 66)

Let us consider the figure of witness here once again as the one with the potential to overcome this "dual" problem. It would be nice to hear that the testimony is profitable - it is in fact, but it is not so easy. It is profitable, but not necessarily financially, and not necessarily immediately. Perhaps acknowledging the benefits of being a witness depends on the accepted vision of a society. For those who choose the concept of the common good, imagining that their commitment will bear fruit, even if they themselves cannot taste it, is not a problem. For those who prefer a utilitarian vision, it may be more difficult. However, I believe that the testimony is the only way to save ethics. Books and lectures aloneeven the finest ones-will not do it. Only the values that are woven into daily activity are able to affect reality and transform it. Ethics needs dialogue and prac-

a tremendous downfall of morals in politics and business. Life progresses faster than our ideas, and so medieval ideas, methods and judgements are constantly applied to the conditions and problems of modern life. [...] Medieval legalism and medieval morals - the basis of the old, social structure - being by their nature [...] opposed to change [are] becoming more and more unable to support the mighty social burden of the modern world [...]" (1987, p. 14).

19 Already at the beginning of the $20^{\text {th }}$ century, such thinkers as Florian Znaniecki (The Decline of Western Civilization) and Oswald Spengler (The Decline of the West) warned against this fall.

20 "The business executive today is not so much concerned that someone may be looking, but that everybody is. And 'everybody' seems to have a different set of ethical standards. This is what causes an executive to agree with Hamlet that "conscience does make cowards of us all"' (Nierenberg, 1987, p. 11). 
tice $^{21}$ to stay alive. It requires a continuous dialogue of words and acts. It is in the interests of consumers to provide the company with an opinion. It encourages economic organizations to explore more deeply the resources of their values in search of the least harmful and acceptable solutions not only by direct users of their products and services.

\section{Conclusions}

[...] in a participatory society no single party is most important, but none can be left out.

Henk J. L. van Luijk (1992, p. 25)

[...] to live so that others can live better after I have gone.

Charles Handy (Alford \& Naughton, 2006, p. 222)

Consumers now have the opportunity, as never before, to respond to the challenge of responsibility. I do not mean starting a bloody revolution but becoming an involved party in economic life. Certainly, filing complaints and suing enterprises is not enough. If buyers do not become more active, they will not be able to enjoy a market that best serves real human development, and not just trying to find the best combination of supply and demand.

The social responsibility of the consumer is aimed at preserving and improving the conditions of the joint presence of market entities so that not all of them can only give best of what they have but also receive what is possible to achieve. Consumers and enterprises simply need each other and cannot meet their goals and their needs on their own. Therefore, the corporate social responsibility should be accompanied by the social responsibility of consumers, to create a real economy of dialogue, and to stimulate a more human-based growth of societies. Enterprises and consumers are not enemies and it makes no sense to ask who should win. ${ }^{22}$ Rather, it is about finding an answer to the question of how they can cooperate and help each other to contribute to the common good of all. Using the language of management one could say that not only enterprises, but also consumers are able and encouraged to broaden their perspective of the way they perceive social reality - from the concept of shareholders and stakeholders-to the model of the common good that surpasses the previous two (cf. Alford \& Naughton, 2006, pp. 38-69).

\footnotetext{
21 "In our pluralistic world of business people and professionals, no matter how much the limits of authority are strained, no theoretical system of ethics can even begin to meet their needs" (Nierenberg, 1987, p. 22).

${ }^{22}$ Unfortunately, the "war" mentality still seems to dominate in the economic sphere. This is manifested, among others, in management and marketing terminology as well as various "richest" and "largest" rankings.
} 
Undoubtedly, enterprises should facilitate and help their clients to communicate their opinion and emphasize the importance of it at all levels of the organization. It is in their interest to find out if buyers share their hierarchy of values. Questions that each company can ask themselves may be as follows: Do we really care about the client? Are we not afraid to tell him the truth? Do we really want the customer to trust us? Do we trust him?

To become more socially responsible, consumers can certainly take care of diligent and lifelong learning in the field of basic economic principles (of course, it is not necessary for everyone to get an MBA). They should require companies to communicate with them in a comprehensible language. Finally, they should boldly show what they think and feel. This may require their time and effort, which may cause doubt as to whether it is worth showing commitment and responsibility. No matter what they do, they are responsible anyway. Even if they do not take responsibility, it lies with them-even if it was only to be responsible in order to avoid social responsibility. We should also remember that consumers are not only responsible for themselves. They are also spokesmen and witnesses for their relatives, friends, neighbors - for all of society and generations to come in the future: for their welfare and well-being. ${ }^{23}$

\section{References}

Alford, H. J., \& Naughton, M. J. (2006). Managing as if faith mattered. Christian social principles in the modern organization. Notre Dame, Indiana: University of Notre Dame Press.

Beck, U. (2002). Risk society: Towards a new modernity (S. Cieśla, Trans.). Warszawa: Wydawnictwo Naukowe SCHOLAR.

Buttiglione, R. (2000). Behind Centesimus Annus. In M. Novak, W. Brailsford, \& C. Heesters (Eds.), A free society reader. Principles for the new millennium. LanhamBoulder-New York-Oxford: Lexington Books.

Delsol, C. (2003). The unlearned lessons of the twentieth century: An essay on late modernity (M. Kowalska, Trans.). Kraków: Znak.

Dylus, A. (2005). Globalizacja. Refleksje etyczne. Wrocław-Warszawa-Kraków: Ossolineum.

Fritsch, A. (2006). Fifty possible ways to challenge over-commercialism. In Earth Healing ( $2^{\text {nd }}$ Edition). http://www.earthhealing.info/fifty.htm

Goodman, W. (1971). Stocks without sin. Harpers, August, 66 [reprinted in: C. D. Stone. (1997). Why shouldn't corporations be socially responsible (J. Sójka, Trans.). In L. V. Ryan, \& J. Sójka (Eds.), Business Ethics. Poznań: "W drodze"].

Goodpaster, K., \& Matthews Jr., J. B. (1997). Czy spótka może mieć sumienie? (E. Dratwa, Trans.). In L. V. Ryan, \& J. Sójka (Eds.), Business Ethics. Poznań: "W drodze".

23 “[...] moralists should not regard individuals as animals and/or gods, but as members of a timebinding class, aware of their debt to the past and conscious of their obligation to the future (Nierenberg, 1987, p. 68). 
John Paul II. (1981, August 25). Speech in Castel Gandolfo.

John Paul II. (1981). Laborem exercens. http://w2.vatican.va/content/john-paul-ii/en/encycli cals/documents/hf_jp-ii_enc_14091981_laborem-exercens.html

John Paul II. (1987). Sollicitudo rei socialis. http://w2.vatican.va/content/john-paul-ii/en/en cyclicals/documents/hf_jp-ii_enc_30121987_sollicitudo-rei-so cialis.html

John Paul II. (1991). Centesimus Annus. http://w2.vatican.va/content/john-paul-ii/en/encyclic cals/documents/hf_jp-ii_enc_01051991_centesimus-annus.html

Jonas, H. (1985). The imperative of responsibility. University of Chicago Press.

Lewicka-Strzałecka, A. (2006). Odpowiedzialność moralna $w$ życiu gospodarczym. Warszawa: Wydawnictwo Instytutu Filozofii i Socjologii Polskiej Akademii Nauk.

van Luijk, H. J. L. (1992). A vision of business in Europe. In J. Mahoney, \& E. Vallance (Eds.), Business ethics in a new Europe. Dordrecht-Boston-London: Kluwer Academic Publishers.

MacIntyre, A. (1997). Why business ethics problems are unsolvable? (A. Zaporowski, Trans.). In L. V. Ryan, \& J. Sójka (Eds.), Business Ethics. Poznań: "W drodze".

Michalski, M. A. (2008). Społeczna odpowiedzialność konsumenta. Annales. Ethics in Economic Life, 11(1), 181-192.

Nierenberg, G. I. (1987). Workable ethics. What you need to succeed in business and life. New York: Nierenberg\&Zeif Publishers.

Second Vatican Council. (1965). Gaudium et spes. The Pastoral Constitution on the Church in the Modern World.

Shaw, R. (2001). Database marketing: strategy and implementation (R. Nowakowski, Trans.). Warszawa: Wydawnictwo Studio Emka/The Economist Books.

Szwarc, M. (2006). Jak wejdę do sklepu, to koniec. Zwierciadło, 11/1921. 